BMJ Paediatrics Open

\section{Decision-making for the infant sleep environment among families with children considered to be at risk of sudden unexpected death in infancy: a systematic review and qualitative metasynthesis}

To cite: Pease A, Garstang JJ, Ellis $\mathrm{C}$, et al. Decision-making for the infant sleep environment among families with children considered to be at risk of sudden unexpected death in infancy: a systematic review and qualitative metasynthesis BMJ Paediatrics Open 2021;5:e000983. doi:10.1136/ bmjpo-2020-000983

- Additional material is published online only. To view, please visit the journal online (http://dx.doi.org/10.1136/ bmjpo-2020-000983).

Received 10 December 2020 Revised 9 February 2021 Accepted 14 February 2021

Check for updates

(C) Author(s) (or their employer(s)) 2021. Re-use permitted under CC BY-NC. No commercial re-use. See rights and permissions. Published by BMJ

For numbered affiliations see end of article.

Correspondence to Dr Anna Pease; a.pease@bristol. ac.uk

\section{ABSTRACT}

Background Advice to families to sleep infants on their backs, avoid smoke exposure, reduce excess bedcovering and avoid specific risks associated with cosleeping has greatly reduced sudden unexpected death in infancy (SUDI) rates worldwide. The fall in rates has not been equal across all groups, and this advice has been less effective for more socially deprived families. Understanding decision-making processes of families with infants at risk would support the development of more effective interventions.

Aim To synthesise the qualitative evidence on parental decision-making for the infant sleep environment among families with children considered to be at increased risk of SUDI.

Methods This study was one of three related reviews of the literature for the Child Safeguarding Practice Review Panel's National Review in England into SUDI in families where the children are considered at risk of harm. A systematic search of eight online databases was carried out in December 2019. Metasynthesis was conducted, with themes extracted from each paper, starting with the earliest publication first.

Results The wider review returned 3367 papers, with 16 papers (across 13 studies) specifically referring to parenta decision-making. Six overall themes were identified from the synthesis: (1) knowledge as different from action; (2) external advice must be credible; (3) comfort, convenience and disruption to the routine; (4) plausibility and mechanisms of protection; (5) meanings of safety and risk mitigation using alternative strategies; and (6) parents' own expertise, experience and instincts.

Conclusion Interventions that are intended to improve the uptake of safer sleep advice in families with infants at risk of sleep-related SUDI need to be based on credible advice with mechanisms of protection that are understandable, consistent with other sources, widened to all carers of the infant and fit within the complex practice of caring for infants.
What is known about the subject?

Sudden unexpected death in infancy deaths have fallen across the general population, but less so for families experiencing social deprivation.

- Improving uptake of safer sleep advice in families with infants at increased risk could save lives.

- Understanding the factors that influence the uptake of this advice could be used to develop effective interventions.

\section{What this study adds?}

Future interventions should go beyond information giving and consider families' experiences, circumstances and perspectives to make interventions more effective.

- They should be 'targeted for effectiveness', meaning that they have been developed with, and established as effective for, those families with infants at increased risk

- They should also consider including wider family and friends, ensuring that all those caring for the infant have access to effective interventions.

\section{INTRODUCTION}

Every year in the UK, 300-400 infants die suddenly and unexpectedly (sudden unexpected death in infancy (SUDI)). ${ }^{1}$ Of these deaths, most (approximately $70 \%$ ) remain unexplained after investigation, labelled sudden infant death syndrome (SIDS) or unascertained. SIDS rates have declined dramatically since the original safe sleep campaigns of the 1990s, with remaining cases now more likely to occur in families experiencing social deprivation. ${ }^{2}$ Alcohol, drugs and cosleeping 
are features of some SUDI deaths where there may be other safeguarding concerns. ${ }^{3}$ Improving the uptake of safer sleep advice in families with children at risk is likely to reduce deaths further, but recommendations about the most effective way to do this are lacking. Understanding the factors that influence decision-making in this group could contribute to the design of large-scale, targeted approaches to risk reduction in families with children at highest risk. ${ }^{4}$ The National Child Safeguarding Practice Review Panel, as part of its review into SUDI, commissioned a wide-ranging literature review on SUDI in families with children considered to be at risk. ${ }^{5}$ The specific review question to be addressed here is 'What does qualitative research tell us about the factors that influence decision-making for the infant sleep environment, in families with children at increased risk of SUDI, and how can we use this insight to improve intervention design and delivery?'

\section{METHODS}

The study protocol was registered with the International Prospective Register of Systematic Reviews (PROSPERO) (PROSPERO number CRD42020165302). The wider review included three related areas of the literature: interventions to improve the uptake of safer sleep advice, interventions to improve engagement with support services and factors that influence decision making for the infant sleep environment. The search strategy and screening methods described here apply to the wider review, while the inclusion and exclusion criteria and data extraction methods are all specific to the decisionmaking review. Our methods, results and discussion are reported in line with the Enhancing Transparency in Reporting the Synthesis of Qualitative Research statement. ${ }^{6}$

Searches of eight online databases took place between 20 and 29 December 2019, listed in online supplemental table 1 with example search terms. Additional searches in January 2020 included emailing all English Child Death Overview Panels, Designated Doctors for Child Death, Designated Doctors for Safeguarding, UK local safeguarding children's partnerships and the membership directory of the International Society for the Study and Prevention of Perinatal and Infant Death.

Snowball searches of eligible and relevant papers' (papers identified from database searches not eligible for inclusion but covering relevant literature) reference lists were also conducted, and any papers meeting eligibility were included.

We included studies of families considered at high risk of SUDI (however defined by individual studies), with children under the age of 1 year, which explored infant sleep position, sleep surfaces, cosleeping (an adult and a baby sleeping on the same surface), bed-sharing (an adult and a baby sleeping in an adult bed together), dummy/pacifier use, swaddling, room sharing (sleep location), infant bedding, exposure to smoke in the home or room temperature. We did not limit by date or language. Definitions of 'high risk' populations included young parental age, low socioeconomic status, limited education, recruitment from disadvantaged areas, or ethnicity with a higher than average SUDI rate.

We excluded studies not using qualitative methodology, those applied to general populations only (with no high risk sampling) and those based in countries outside Western Europe, North America or Australasia, given the risk factors and associated infant care practices, are broadly similar in these regions.

Four authors (AP, JJG, DW and CE) screened all titles and abstracts with conflicts resolved by discussion and examination of the full text. Screening of full-text articles led to final group discussions for included papers.

The quality of all included studies was assessed using the Quality Assessment Tool for Studies with Diverse Designs (QATSDD) $^{7}$ and Noyes and Popay's ${ }^{8}$ construct of 'thickness of the description' as a key indicator of the external validity of qualitative evidence. ${ }^{9}$ Quality assessment of qualitative studies is a contested area due to the interpretive nature of qualitative evidence. ${ }^{10}{ }^{11}$ Here we used the assessment tool to ensure a 'close reading' of the papers ${ }^{12}$ and to assess the relative contribution of each paper to the synthesis themes. Each paper was assessed (by AP and $\mathrm{CE}$ ) for 'thickness of description', that is, whether the description provided clear and detailed evidence for the study authors' interpretation of their data, which gives an indication of the quality of the evidence in the included papers.

A metasynthesis of the qualitative data enabled themes from included studies to be extracted into an iterative framework, in Excel Version 2101. ${ }^{81314}$ The framework was developed as themes were added, rather than being decided prior to data extraction. This was done to mirror the inductive thematic approach taken by most qualitative research where data from interviews or focus groups are examined to look for patterns and commonalities rather than trying to make them fit an a priori model. ${ }^{14}$ Thus the data extraction and synthesis took place concurrently. Two authors (AP and $\mathrm{CE}$ ) extracted the themes and contributed to the framework, with agreement on the final themes reached through discussion, including the other members of the team. Where authors' own papers were included in the review, these were extracted and synthesised by a member of the team who was not involved in the included study.

\section{Patient and public involvement}

There was no patient or public involvement in this study.

\section{RESULTS}

Following deduplication, 3367 records were screened (figure 1) and 16 papers from 13 studies were included. Tables 1-3 show study characteristics, split by interviews (five papers), focus groups (five papers) and mixed interviews and focus groups (six papers from three studies). 


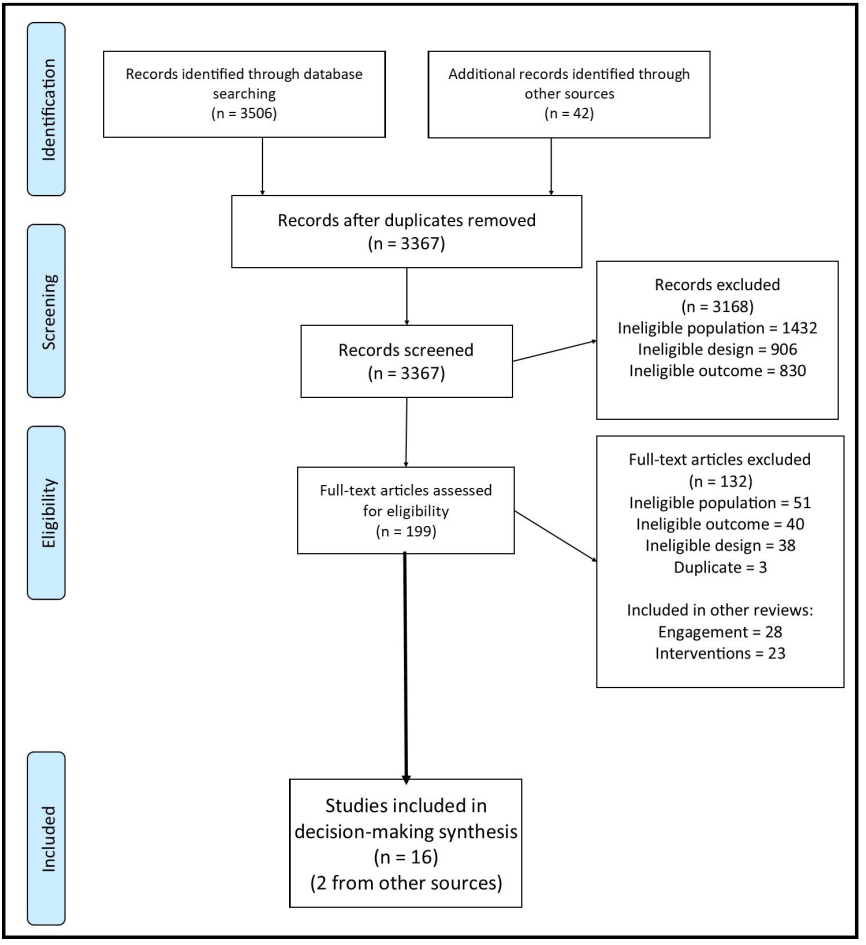

Figure 1 Preferred Reporting Items for Systematic Reviews and Meta-Analyses flow diagram of literature search and selection process.

The contribution of each paper to the overall synthesis, portrayed as 'thickness', is shown in online supplemental table 2. The synthesis themes were supported by 'thick description' (indicating better qualitative evidence) from between 4 and 10 studies per theme.

Spanning the years 2000-2019, over half $(7 / 13)$ were conducted in the USA, ${ }^{15-24}$ two from New Zealand $^{25}{ }^{26}$ and four from the UK. ${ }^{27-30}$ Six (46\%) included fathers ${ }^{15} 1620222528$; eight used thematic analysis $^{16}{ }^{1724-28 ~} 30$; five used grounded theory ${ }^{18-2022} 23$; two used content analysis ${ }^{1521}$; and one used interpretative phenomenological analysis. ${ }^{29}$

Participant numbers ranged from 5 to 136 mainly selected through healthcare settings or communitybased centres. Definitions of high risk varied, with two studies using ethnicity, ${ }^{20}{ }^{25}$ one using education level, ${ }^{16}$ five recruiting from deprived areas, ${ }^{21} 22262830$ two using young maternal age ${ }^{1523}$ and three studies using a combination of factors (six papers). ${ }^{17-19} 242729$

Using the QATSDD, quality scores ranged from 19 to 42 , with percentages ranging from $45 \%$ to $100 \%$. Of 16 papers, 1 scored under 50\%; 8 scored 50\%-75\%; and 7 scored over $75 \%$. No papers were excluded from the metasynthesis based on their score. After analysis, weaker papers were compared with stronger ones to look for differences in theme contributions and none were found.

Six themes were developed, which provide the subheadings presented as follows: (1) knowledge as different from action; (2) external advice must be credible; (3) comfort, convenience and disruption to the routine; (4) plausibility and mechanisms of protection; (5) meanings of safety and risk mitigation using alternative strategies; and (6) parents' own expertise, experience and instincts.

\section{Knowledge as different from action}

When it came to knowledge of safer sleep, hearing advice about reducing the risks in the infant sleep environment was not always enough to influence behaviour. Miller $e t$ al found examples of this where participants would cite the advice, then give reasons why it did not happen with their baby ${ }^{28}$ Clarke concluded that 'It is too simplistic to assume that knowledge of risks leads to behaviour change' (p66) ${ }^{26}$ Mosley et al described a 'chorus' of the back to sleep message, but this was not translated into action. ${ }^{16}$ Crane and Ball $^{30}$ described comprehensive knowledge, but variability in implementation. Many of the studies then attempted to map the thinking and behaviour that took up the space between having knowledge and actual practice. ${ }^{262930}$ The detailed reasons for this lack of impact from knowledge alone are described in the other five themes in this analysis, but it emerged as a theme in its own right, given that the majority of past interventions that have proven to be successful in reducing sudden and unexpected deaths in infancy have 'information giving' at their core. ${ }^{31}$

\section{External advice must be credible}

Across most studies, there were descriptions of reactions to safer sleep advice, where credibility was called into question. ${ }^{16}$ 26-30 Yuma-Guerrero et al found that some participants felt that the advice given to them was 'ridiculous', for example, where mothers felt advice not to overwrap an infant conflicted with an infant's need to keep warm. ${ }^{15}$ Miller et $a l^{28}$ reported confusion as a major theme, with parents citing conflicting advice from health professionals. Mosely et al ${ }^{16}$ found evidence of 'tension' between external advisors to parents, in particular, between health professionals and older family members. Pease $e t a l^{27}$ found credibility of advice to be lacking where didactic approaches were used by health professionals. Ellis ${ }^{29}$ describes 'bad advice' where mothers described several factors that contributed to ignoring advice, including inconsistencies and perceptions of 'dinosaur' (outdated) advice that they felt did not apply to them. Clarke's study found that health professionals were seen as only one of a range of potential credible sources of information which included partners, peers, family members and the internet. ${ }^{26}$

\section{Comfort, convenience and disruption to the routine}

Infant sleep position was commonly reported in relation to comfort where parents perceived infants as more comfortable in unsafe sleep positions. ${ }^{152325}$ Comfort was also related to how parents perceived infants to be in charge of sleep decisions, citing infant preference for certain positions or environments. ${ }^{29}$ Decisions to bed-share, especially if breast feeding, were often cited as related to convenience to minimise time spent awake during the night. ${ }^{15222529}$ Similarly, changes to the infant 
Table 1 Characteristics of included papers on decision-making for the infant sleep environment in families with children considered to be at high risk of SUDI: studies using interviews

\begin{tabular}{|c|c|c|c|c|c|c|}
\hline $\begin{array}{l}\text { Lead author } \\
\text { Year } \\
\text { Country }\end{array}$ & $\begin{array}{l}\text { Sample } \\
\text { size }\end{array}$ & Study aim & Target population & $\begin{array}{l}\text { Topic guide broad } \\
\text { categories }\end{array}$ & Analysis & $\begin{array}{l}\text { QATSDD } \\
\text { score (\%) }\end{array}$ \\
\hline $\begin{array}{l}\text { Miller } \\
2008 \\
\text { UK }^{28}\end{array}$ & 16 & $\begin{array}{l}\text { To explore parents' } \\
\text { understanding of } \\
\text { the recommended } \\
\text { cot death prevention } \\
\text { strategies and sleep } \\
\text { practices }\end{array}$ & $\begin{array}{l}\text { Parents of infants } \\
0-6 \text { months, } \\
\text { recruitment in } \\
\text { disadvantaged area }\end{array}$ & $\begin{array}{l}\text { Advice given and } \\
\text { current infant sleep } \\
\text { practices }\end{array}$ & Thematic analysis & $27 / 42$ (64.3) \\
\hline $\begin{array}{l}\text { Crane and } \\
\text { Ball } \\
2016 \\
\text { UK }^{30}\end{array}$ & 46 & $\begin{array}{l}\text { How white British and } \\
\text { Pakistani mothers } \\
\text { in Bradford recall, } \\
\text { understand and } \\
\text { interpret SIDS-reduction } \\
\text { guidance }\end{array}$ & $\begin{array}{l}\text { Mothers residing in } \\
\text { socioeconomically } \\
\text { deprived inner city } \\
\text { areas, with infants } \\
\text { aged 8-12 weeks }\end{array}$ & $\begin{array}{l}\text { Feeding, baby's } \\
\text { sleep (surface, } \\
\text { room, position, } \\
\text { swaddling and } \\
\text { temperature), day } \\
\text { care, temperature, } \\
\text { dummy use, cultural } \\
\text { norms and health } \\
\text { information }\end{array}$ & Thematic analysis & $30 / 42(71.4)$ \\
\hline
\end{tabular}

\begin{tabular}{|c|c|c|c|c|c|c|}
\hline $\begin{array}{l}\text { Clarke } \\
2016 \\
\text { New Zealand } \\
\text { (Master's }_{\text {thesis) }}^{26}\end{array}$ & 13 & $\begin{array}{l}\text { Maternal values, safe } \\
\text { sleep knowledge and } \\
\text { how practical realities } \\
\text { influence decision- } \\
\text { making in the night-time } \\
\text { care of infants. }\end{array}$ & $\begin{array}{l}\text { Mothers living } \\
\text { in economically } \\
\text { deprived areas } \\
\text { with babies under } \\
6 \text { months old }\end{array}$ & $\begin{array}{l}\text { Night-time care, } \\
\text { partner involvement, } \\
\text { advice, sources, } \\
\text { trust, conflicting } \\
\text { information, } \\
\text { mothering, safety } \\
\text { and sleep, and risk } \\
\text { taking (self and } \\
\text { others) }\end{array}$ & Thematic analysis & $32 / 42$ (76.2) \\
\hline $\begin{array}{l}\text { Pease et al } \\
2017 \\
\text { UK }^{27}\end{array}$ & 20 & $\begin{array}{l}\text { To understand why } \\
\text { some mothers in the } \\
\text { UK do not follow the } \\
\text { recommended SIDS } \\
\text { advice, in particular, } \\
\text { mothers who are more } \\
\text { at risk of suffering a } \\
\text { SIDS tragedy }\end{array}$ & $\begin{array}{l}\text { Mothers with three } \\
\text { or more from: } \\
\text { maternal age of <26 } \\
\text { years, three or more } \\
\text { children, smoking } \\
\text { during pregnancy, } \\
\text { Index of Multiple } \\
\text { Deprivation score in } \\
\text { the most deprived } \\
\text { quintile }\end{array}$ & $\begin{array}{l}\text { infant sleep } \\
\text { position, } \\
\text { cosleeping, } \\
\text { smoking, dummy } \\
\text { use, feeding and } \\
\text { disrupted routines }\end{array}$ & Thematic analysis & 28/42 (66.7) \\
\hline $\begin{array}{l}\text { Ellis } \\
2019 \\
\text { UK (PhD } \\
\text { thesis) }\end{array}$ & 5 & $\begin{array}{l}\text { Lived experience } \\
\text { of young first-time } \\
\text { mothers identified as } \\
\text { being at increased risk } \\
\text { of experiencing SUDI, } \\
\text { their understanding of } \\
\text { safe sleep practices, } \\
\text { what factors influence } \\
\text { their decision-making } \\
\text { and behaviour in } \\
\text { relation to their infant's } \\
\text { sleep environment, and } \\
\text { whether infant care } \\
\text { practices change over } \\
\text { time }\end{array}$ & $\begin{array}{l}\text { White British } \\
\text { pregnant women, } \\
\text { first child, aged } \\
\text { 16-21 years, with } \\
\text { at least one of } \\
\text { smoking; misuse } \\
\text { of drugs or alcohol; } \\
\text { unemployment or } \\
\text { low income; reported } \\
\text { housing issues } \\
\text { (rented, overcrowding } \\
\text { and homelessness/ } \\
\text { sofa surfing) }\end{array}$ & $\begin{array}{l}\text { Understanding } \\
\text { of safe sleep } \\
\text { practices, what } \\
\text { factors influence } \\
\text { their decision- } \\
\text { making and } \\
\text { behaviour in relation } \\
\text { to their infant's } \\
\text { sleep environment } \\
\text { and whether infant } \\
\text { care practices } \\
\text { change over time }\end{array}$ & $\begin{array}{l}\text { Interpretative } \\
\text { phenomenological } \\
\text { analysis }\end{array}$ & $42 / 42(100.0)$ \\
\hline
\end{tabular}

QATSDD, Quality Assessment Tool for Studies with Diverse Designs; SIDS, sudden infant death syndrome; SUDI, sudden unexpected death in infancy.

sleep environment that resulted from disruptions to the routine almost always related to enabling both parent and child to get enough sleep. ${ }^{19} 21222627$ Disruptions to the routine involved a range of factors including changes to the sleep environment due to tiredness or sleep deprivation, changes at weekends and disruptions to the wider family environment. Clarke describes how 'makeshift' sleep environments were designed to be conducive to sleep rather than safety. ${ }^{26}$ Pease $e t a l^{27}$ outlined two types of disruption: those that were unintentional, such as falling asleep with the baby on the sofa, or intentional but rare, with mothers expressing a certain amount of 
Table 2 Characteristics of included papers on decision-making for the infant sleep environment in families with children considered to be at high risk of SUDI: studies using focus groups

\begin{tabular}{|c|c|c|c|c|c|c|}
\hline $\begin{array}{l}\text { Lead author } \\
\text { Year } \\
\text { Country }\end{array}$ & $\begin{array}{l}\text { Sample } \\
\text { size }\end{array}$ & Study aim & $\begin{array}{l}\text { Target } \\
\text { population }\end{array}$ & $\begin{array}{l}\text { Topic guide broad } \\
\text { categories }\end{array}$ & Analysis & $\begin{array}{l}\text { QATSDD score } \\
(\%)\end{array}$ \\
\hline $\begin{array}{l}\text { Chianese } \\
2009 \\
\text { USA }^{22}\end{array}$ & 28 & $\begin{array}{l}\text { To understand } \\
\text { parents' motivations } \\
\text { for bed-sharing with } \\
\text { their infants, their } \\
\text { beliefs about safety } \\
\text { concerns and their } \\
\text { attitudes about bed- } \\
\text { sharing advice }\end{array}$ & $\begin{array}{l}\text { Primary } \\
\text { caregivers } \\
\text { of infants } \\
1-6 \text { months, } \\
\text { bed-sharing } \\
\text { regularly; } \\
\text { recruitment from } \\
\text { inner city centre } \\
\text { serving families } \\
\text { in receipt of } \\
\text { medical benefit }\end{array}$ & $\begin{array}{l}\text { Experiences sleeping } \\
\text { with baby, changes } \\
\text { over time, advice and } \\
\text { concerns }\end{array}$ & $\begin{array}{l}\text { Grounded } \\
\text { theory }\end{array}$ & 39/42 (92.9) \\
\hline $\begin{array}{l}\text { Yuma-Guerrero } \\
2013 \\
\text { USA }^{15}\end{array}$ & 58 & $\begin{array}{l}\text { Understanding } \\
\text { pregnant and } \\
\text { parenting teenagers' } \\
\text { child safety beliefs } \\
\text { and practices related } \\
\text { to injury-related death } \\
\text { for young children }\end{array}$ & $\begin{array}{l}\text { Teenage parents } \\
\text { enrolled at } \\
\text { participating } \\
\text { school, pregnant } \\
\text { or parenting, } \\
\text { spoke English or } \\
\text { Spanish }\end{array}$ & $\begin{array}{l}\text { Worries, biggest } \\
\text { threat, where does } \\
\text { baby sleep, location, } \\
\text { surface, anything } \\
\text { around baby, wearing, } \\
\text { position, advice }\end{array}$ & $\begin{array}{l}\text { Content } \\
\text { analysis }\end{array}$ & $22 / 42(52.4)$ \\
\hline $\begin{array}{l}\text { Gaydos } \\
2015 \\
\text { USA }^{21}\end{array}$ & 60 & $\begin{array}{l}\text { Understand how } \\
\text { low-income, African- } \\
\text { American mothers } \\
\text { understand and } \\
\text { act on safe sleep } \\
\text { recommendations for } \\
\text { newborns and how } \\
\text { providers counsel } \\
\text { these mothers }\end{array}$ & $\begin{array}{l}\text { African- } \\
\text { American } \\
\text { mothers, over } \\
18 \text {, spoke } \\
\text { English, first- } \\
\text { time mother } \\
\text { of infant aged } \\
<6 \text { months }\end{array}$ & $\begin{array}{l}\text { Safe sleep practices, } \\
\text { reasons for bed- } \\
\text { sharing, reasons for } \\
\text { prone or side position, } \\
\text { understanding of } \\
\text { recommendations } \\
\text { from health workers }\end{array}$ & $\begin{array}{l}\text { Content } \\
\text { analysis }\end{array}$ & $24 / 42(57.1)$ \\
\hline $\begin{array}{l}\text { Herman } \\
2015 \\
\text { USA }^{20}\end{array}$ & 73 & $\begin{array}{l}\text { Beliefs among } \\
\text { African-American } \\
\text { and American Indian } \\
\text { families about infant } \\
\text { safe sleep practices, } \\
\text { barriers and more } \\
\text { effective messaging } \\
\text { strategies }\end{array}$ & $\begin{array}{l}\text { African- } \\
\text { American or } \\
\text { American Indian } \\
\text { mothers with } \\
\text { babies under } \\
2 \text { years or their } \\
\text { 'supporters' }\end{array}$ & $\begin{array}{l}\text { Infant safe sleep } \\
\text { practices, safe sleep } \\
\text { messages }\end{array}$ & $\begin{array}{l}\text { Grounded } \\
\text { theory }\end{array}$ & 19/42 (45.2) \\
\hline
\end{tabular}

QATSDD, Quality Assessment Tool for Studies with Diverse Designs; SUDI, sudden unexpected death in infancy.

tolerance for unsafe sleeping situations, as long as they were not the norm; for example, sofa sleeping at the weekends was seen as less risky than as a regular practice. Ellis too describes occasional situations where preservation of sleep for parents is prioritised over maintaining the safe infant sleep environment. ${ }^{29}$

\section{Plausibility and mechanisms of protection}

This theme relates to parent interpretations of how safer sleep messages confer protection for their infant. Miller et al observed that some parents were engaging in safe infant sleep practices but were unaware these practices reduced risks, and postulated that if more parents knew why the advice reduces the risk, they may be more likely to follow it. ${ }^{28}$ Moon et al found that where mothers were unable to connect a mechanism of protection to a piece of safer sleep advice, it left room for doubt and ultimately reasons not to follow it. ${ }^{17}$ They also noted that, where advice was seen as plausible, this was connected to understandings of how an infant might suffocate, especially in advice about sleeping position and bedding. The importance of understanding how the advice protects infants was echoed in the studies by Herman et al, Caraballo et al and Crane and Ball. ${ }^{20} 230$ Joyner et al looked specifically at dummy/pacifier use and again found that parents were 
Table 3 Characteristics of included qualitative papers on decision making for the infant sleep environment in families with children considered to be at high risk of SUDI: studies using interviews and focus groups

\section{Lead author}

Year

Sample

Country

size

Study aim

Target population
Maori parents or
caregivers of children
under 12 months old

Topic guide broad categories

Tipene-Leach

2000

26

New Zealand ${ }^{25}$

Increase understanding of present-day Maori infant care practices

136

Mosley

2007

$\mathrm{USA}^{16}$

$\begin{array}{lll}\begin{array}{l}\text { Joyner } \\ 2010 \\ \text { USA }^{19 *}\end{array} & 83 & \begin{array}{l}\text { To investigate, using } \\ \text { qualitative methods, } \\ \text { factors influencing } \\ \text { African-American } \\ \text { parents' decisions } \\ \text { regarding infant sleep } \\ \text { location (room location } \\ \text { and sleep surface) }\end{array} \\ & & \begin{array}{l}\text { Perceptions about SIDS } \\ \text { in African-American } \\ \text { poon }\end{array} \\ \begin{array}{l}\text { parents and how these } \\ \text { influence decisions }\end{array}\end{array}$

\begin{tabular}{|c|c|c|}
\hline $\begin{array}{l}\text { Аjao } \\
2011 \\
\text { USA }^{24 *}\end{array}$ & 83 & $\begin{array}{l}\text { To examine factors } \\
\text { influencing decisions by } \\
\text { black parents regarding } \\
\text { use of soft bedding and } \\
\text { sleep surfaces for their } \\
\text { infants }\end{array}$ \\
\hline
\end{tabular}

Joyner

2016

$\mathrm{USA}^{18 *}$

$\begin{array}{ll}\text { To determine decision- } & \text { Parents of children } \\ \text { making factors for infant } & \text { under } 12 \text { months, } \\ \text { sleep position among } & \text { education level (not } \\ \text { low-income parents and } & \text { specified or reported) } \\ \text { other relatives } & \begin{array}{l}\text { used as proxy for } \\ \text { income level }\end{array}\end{array}$

African-American mothers with infants aged $<6$ months, born in the USA; low parental education; eligible for Medicaid and supplementation programme

African-American mothers with infants aged $<6$ months, born in the USA, low parental education, eligible for Medicaid and supplementation programme

African-American mothers with infants aged $<6$ months, born in the USA, low parental education, eligible for Medicaid and supplementation programme

83 African-American
parental reasons for pacifier use or non-use, and whether knowledge of the association with decreased SIDS risk African-American mothers with infants aged $<6$ months, born in the USA, low parental education, eligible for Medicaid changes decisions about and supplementation pacifier use traditional practices, health and well-being, support available pillows and blankets

Infant sleep Thematic 22/42 (52.4)

arrangements, analysis

Sleeping place, advice, Thematic $\quad 30 / 42$ (71.4)
trust analysis

QATSDD score (\%)

\begin{tabular}{ll} 
Analysis & $\begin{array}{l}\text { QATSDD } \\
\text { score (\%) }\end{array}$ \\
\hline Thematic & $22 / 42(52.4)$
\end{tabular}

Sleep location, bed- Grounded $32 / 42(76.2)$ sharing, room sharing, theory

*Denotes papers relating to the same study.

QATSDD, Quality Assessment Tool for Studies with Diverse Designs; SIDS, sudden infant death syndrome; SUDI, sudden unexpected death in infancy.

curious about possible mechanisms of protection. ${ }^{18}$ Both Pease $e t a l$ and Ellis found that a lack of understanding of reasons for advice were tied to feelings of being 'told' or just given rules and expected to follow them without question. 2729

\section{Meanings of safety and risk mitigation using alternative strategies}

Most studies described how parents were concerned about infant safety and had developed ways to interpret threats to safety within the sleep environment. Chianese $e t a l$ and Joyner $e t$ al both describe safety as a reason for bed-sharing with infants, predominantly to improve monitoring of infants and protect against external threats, including gunfire, house fire, or vermin. ${ }^{19}{ }^{22}$ Bedsharing for closeness, which improved perceived infant monitoring during illness was also common. ${ }^{162023}$ These meanings of safety often extended into a range of infant sleep practices aimed to improve safety, but inadvertently 
increased risk. Examples of this include the use of cot bumpers (which are not recommended in most national safe sleep campaigns, eg, in the UK, USA, Australia or New Zealand) to prevent injury to infants from cot bars, ${ }^{23}$ pillows (which also constitute a hazard) in bed-sharing scenarios to prevent rolling or falling ${ }^{21}$ and movement monitors in place of back sleeping. ${ }^{26}{ }^{27}$ Studies reported parents found it hard to accept risk reduction advice for something seen as random, fated or within the context of destiny. ${ }^{17} 1920$ This made filling in their own safety strategies more palatable, as seen by Ellis. ${ }^{29}$ Mothers also used increased checking of the infant while asleep as a strategy to reduce anxiety about sleep environment risks. ${ }^{1726} 27$

\section{Parents' own expertise, experience and instincts}

The final theme explores meanings of parenthood and factors which influence how safer sleep advice is implemented. Tipene-Leach et al describe how parents need to be autonomous in their parenting and how advice that conflicted with their own instincts provided a source of tension. ${ }^{25}$ Similarly, Clarke describes the conflict between intuition and 'doing it by the book', ${ }^{26}$ and Ellis explored both validation and expertise as important to young parents. ${ }^{29}$ In development of expertise, a parent's previous experience was frequently related to reasons given for not following safer sleep advice, ${ }^{15} 20$ illustrated by this quote shared by Yuma-Guerrero et al: 'I did this with you when you were little, and you were fine ${ }^{15}$ Related to both experience and expertise were themes that described how parents used their instincts while making decisions for the infant sleep environment. This was particularly evident in papers where parents described cosleeping scenarios as safe because of their ability to know where their infant was despite also being asleep. ${ }^{16202227}$

\section{DISCUSSION}

The themes identified here describe how knowledge without understanding is insufficient and conversations work best where trust and credibility have been established. In addition to safety, parents want to understand the mechanisms of protection incorporated with advice that recognises their expertise, world views and priorities for sleep. The synthesis uncovered plausibility as a key factor in how advice is interpreted. Describing the mechanisms of protection connected to safer sleep advice may help parents' adherence by increasing trust in the messages. Interventions that educate parents on the physiological safety needs of a sleeping infant may be more effective at mitigating some risks. Interventions that include a risk-planning element should also be tested to see if unintended, unsafe cosleeping can be avoided. Parents/carers often trusted their own instincts where advice was not convincing enough, and so tailoring safer sleep conversations within families' experiences may provide a platform for advice to be more acceptable.
Our grey literature search and snowballing approach suggest our search terms were comprehensive, our agreement rate on selection was high and enough papers met our inclusion criteria allowing for meaningful synthesis. There are limitations: our use of a checklist approach to quality appraisal is somewhat subjective and appraisals differ between journal publications and theses, as the latter allow for much more detail to be included. The usefulness of appraisal in qualitative metasynthesis is debated, ${ }^{10}$ and we decided not to exclude any papers based on quality appraisal scores, given that research in this area is limited, and the contribution of individual papers would only be apparent during synthesis. We relied on individual studies' definitions of high risk; therefore, our included studies relate to a variety of populations. Given infant care practices and sleep environments are culture-specific, this was appropriate, but care must be taken to consider the specific circumstances of families with children considered to be at high risk of SUDI within each country, and this may be particularly true of any future interventions targeted to individual ethnic groups who are rarely homogenous in their level of risk for SUDI. Limiting our searches to papers from Western Europe, North America and Australasia also means that our findings may not be generalisable outside of these regions.

The dominant assumption of the last 30 years about parental decision making for infant safe sleep is that giving information at the population level leads to adoption of safer sleep practices. While this has worked in certain contexts, it has failed those from lower socioeconomic groups. ${ }^{32}$ Context certainly played a role in the success of the original 'Back To Sleep campaign', which took place when parental and societal concern about SIDS was high; deaths occurred across socioeconomic groups; and high profile cases in the UK brought public awareness of the risks and prevention strategies. ${ }^{33}$ Targeting those with more complex barriers to adopting messages is where our greatest challenge now lies. In an overview of the behaviour change techniques associated with infant safe sleep interventions, Moon $e t a l^{\beta 1}$ describe five common types of intervention: health messaging, education of professionals, breaking down barriers, using culture and tradition, and mandates via legislation and regulation. The authors recommend in-depth understanding of the barriers to safer sleep and formal process evaluations to improve insights into how interventions might work. We hope this review of qualitative literature will contribute to the development of effective interventions within these broad categories by providing valuable insights into some of the decision-making processes of families with infants at increased risk of SUDI.

\section{RECOMMENDATIONS}

Reducing unexpected infant deaths in families with infants at increased risk of SUDI requires engaging with the complex factors that influence how decisions are 
made for the infant sleep environment. We recommend that future interventions:

- Go beyond information giving and consider families' experiences, circumstances and perspectives, to make interventions more effective.

- Should be 'targeted for effectiveness', meaning that they have been developed with, and established as effective for, those families with infants at increased risk.

- Consider and include wider family and friends, ensuring that all those caring for the infant have access to effective interventions.

- Acknowledge the complexity of infant care and support parents with planning for safety at every sleep.

- Describe the mechanisms of protection connected to safer sleep advice, to support adherence by increasing understanding and trust in the messages.

\section{Author affiliations \\ ${ }^{1}$ Centre for Academic Child Health, University of Bristol Medical School, Bristol, UK \\ ${ }^{2}$ Children and Family Services, Birmingham Community Healthcare NHS Trust, \\ Aston, UK \\ ${ }^{3}$ Institute of Applied Health Research, University of Birmingham, Birmingham, UK \\ ${ }^{4}$ Department of Nursing, Midwifery and Health, University of Northumbria at \\ Newcastle, Newcastle upon Tyne, UK \\ ${ }^{5}$ Children and Families Research Centre, School for Policy Studies, University of \\ Bristol, Bristol, UK \\ ${ }^{6}$ Centre for Academic Primary Care, University of Bristol Medical School, Bristol, UK}

\section{Twitter Anna Pease @AnnaSPease}

Contributors AP PSB, PJF, CE, JJG and DW led the review, designed the scope of the work and wrote the protocol. CC and Jl provided expert qualitative synthesis advice and supported the metasynthesis, assessment of 'thickness' and development of themes. AP conducted the searches with support on terms from PJF, PSB, CE, JJG and DW. CE, JJG, AP and DW screened the titles, abstracts and full texts and discussed final papers for inclusion. AP and CE extracted the characteristic data and conducted the synthesis with support from CC and $\mathrm{Jl}$. Themes were discussed between all authors via input into drafts of the final report. All authors contributed to the writing of the manuscript drafts, providing comments and changes until a final manuscript for submission was agreed.

Funding This work was commissioned by the Child Safeguarding Practice Review Panel as part of its review into sudden unexpected death in infancy. This work was supported by the NHS Bristol, North Somerset and South Gloucestershire Clinical Commissioning Group Launching Fellowship held by Dr Anna Pease.

Competing interests AP, DW, PSB, JJG, PJF and CE received a grant from the Department for Education to conduct the literature review as part of the National Safeguarding Practice Review. AP and CE were authors on two of the studies, which met the inclusion criteria of the review. These studies were extracted and synthesised by members of the team not involved in those studies.

Patient consent for publication Not required.

Provenance and peer review Not commissioned; externally peer reviewed.

Data availability statement Data sharing was not applicable as no datasets were generated and/or analysed for this study. The data used in this synthesis are all available and published online.

Supplemental material This content has been supplied by the author(s). It has not been vetted by BMJ Publishing Group Limited (BMJ) and may not have been peer-reviewed. Any opinions or recommendations discussed are solely those of the author(s) and are not endorsed by BMJ. BMJ disclaims all liability and responsibility arising from any reliance placed on the content. Where the content includes any translated material, BMJ does not warrant the accuracy and reliability of the translations (including but not limited to local regulations, clinical guidelines, terminology, drug names and drug dosages), and is not responsible for any error and/or omissions arising from translation and adaptation or otherwise.
Open access This is an open access article distributed in accordance with the Creative Commons Attribution Non Commercial (CC BY-NC 4.0) license, which permits others to distribute, remix, adapt, build upon this work non-commercially, and license their derivative works on different terms, provided the original work is properly cited, appropriate credit is given, any changes made indicated, and the use is non-commercial. See: http://creativecommons.org/licenses/by-nc/4.0/.

\section{ORCID iDs}

Anna Pease http://orcid.org/0000-0002-3472-1047

Joanna J Garstang http://orcid.org/0000-0001-9268-0581

Catherine Ellis http://orcid.org/0000-0001-6739-8314

Debbie Watson http://orcid.org/0000-0001-5467-3604

Jenny Ingram http://orcid.org/0000-0003-2366-008X

Christie Cabral http://orcid.org/0000-0002-9884-0555

Peter S Blair http://orcid.org/0000-0002-7832-8087

Peter J Fleming http://orcid.org/0000-0003-2521-5764

\section{REFERENCES}

1 Office for National Statistics. Child and infant mortality in England and Wales, 2017. Available: https://www.ons.gov.uk/peoplepopula tionandcommunity/birthsdeathsandmarriages/deaths/bulletins/chil dhoodinfantandperinatalmortalityinenglandandwales/2017

2 Blair PS, Sidebotham P, Berry PJ, et al. Major epidemiological changes in sudden infant death syndrome: a 20 -year populationbased study in the UK. Lancet 2006;367:314-9.

3 Garstang JJ, Sidebotham P. Qualitative analysis of serious case reviews into unexpected infant deaths. Arch Dis Child 2019;104:30-6.

4 Salm Ward TC, Balfour GM. Infant safe sleep interventions, 19902015: a review. J Community Health 2016;41:180-96.

5 National Child Safeguarding Practice Review Panel. Out of routine: a review of sudden unexpected death in infancy (SUDI) in families where the children are considered at risk of significant harm. crown copyright, 2020. Available: https://assets.publishing.service.gov.uk/ government/uploads/system/uploads/attachment_data/file/901091/ DfE Death in infancy review.pdf

6 Tong A, Flemming K, Mclnnes E, et al. Enhancing transparency in reporting the synthesis of qualitative research: ENTREQ. BMC Med Res Methodol 2012:12:181

7 Sirriyeh R, Lawton R, Gardner P, et al. Reviewing studies with diverse designs: the development and evaluation of a new tool. $J$ Eval Clin Pract 2012;18:746-52.

8 Noyes J, Popay J. Directly observed therapy and tuberculosis: how can a systematic review of qualitative research contribute to improving services? A qualitative meta-synthesis. J Adv Nurs 2007; $57: 227-43$

9 Lincoln YS, Guba EG. But is it rigorous? Trustworthiness and authenticity in naturalistic evaluation. New Directions for Program Evaluation 1986:1986:73-84.

10 Hannes K. Critical appraisal of qualitative research. In: Noyes JBA, Hannes K, Harden A, et al, eds. Supplementary guidance for inclusion of qualitative research in Cochrane systematic reviews of interventions. version 1. Cochrane Collaboration Qualitative Methods Group, 2011.

11 Majid U, Vanstone M. Appraising qualitative research for evidence syntheses: a compendium of quality appraisal tools. Qual Health Res 2018;28:2115-31.

12 Cunningham M, France EF, Ring N, et al. Developing a reporting guideline to improve meta-ethnography in health research: the eMERGe mixed-methods study. Health Serv Deliv Res 2019;7:1-116.

13 Microsoft Corporation. Microsoft Excel, 2018. Available: https:// office.microsoft.com/excel

14 Nye E, Melendez-Torres GJ, Bonell C. Origins, methods and advances in qualitative meta-synthesis. Rev Educ 2016;4:57-79.

15 Yuma-Guerrero PJ, Duzinski SV, Brown JM, et al. Perceptions of injury and prevention practices among pregnant and parenting teenagers. J Trauma Nurs 2013;20:3-9.

16 Mosley JM, Daily Stokes S, Ulmer A. Infant sleep position: discerning knowledge from practice. Am J Health Behav 2007;31:573-82.

17 Moon RY, Oden RP, Joyner BL, et al. Qualitative analysis of beliefs and perceptions about sudden infant death syndrome in AfricanAmerican mothers: implications for safe sleep recommendations. $J$ Pediatr 2010:157:92-7.

18 Joyner BL, Oden RP, Moon RY. Reasons for Pacifier use and nonuse in African-Americans: does knowledge of reduced SIDS risk change parents' minds? J Immigr Minor Health 2016;18:402-10. 
19 Joyner BL, Oden RP, Ajao TI, et al. Where should my baby sleep: a qualitative study of African American infant sleep location decisions. J Natl Med Assoc 2010;102:881-9

20 Herman S, Adkins M, Moon RY. Knowledge and beliefs of AfricanAmerican and American Indian parents and supporters about infant safe sleep. J Community Health 2015;40:12-19.

21 Gaydos LM, Blake SC, Gazmararian JA, et al. Revisiting safe sleep recommendations for African-American infants: why current counseling is insufficient. Matern Child Health J 2015;19:496-503.

22 Chianese J, Ploof D, Trovato C, et al. Inner-City caregivers' perspectives on bed sharing with their infants. Acad Pediatr 2009;9:26-32.

23 Caraballo M, Shimasaki S, Johnston K, et al. Knowledge, Attitudes, and Risk for Sudden Unexpected Infant Death in Children of Adolescent Mothers: A Qualitative Study. J Pediatr 2016;174:78-83.

24 Ajao TI, Oden RP, Joyner BL, et al. Decisions of black parents about infant bedding and sleep surfaces: a qualitative study. Pediatrics 2011;128:494-502.

25 Tipene-Leach D, Abel S, Finau SA, et al. Maori infant care practices: implications for health messages, infant care services and SIDS prevention in Maori communities. Pac Health Dialog 2000;7:29-37.

26 Clarke J. Velcro babies: A Qualitative Study Exploring Maternal Motivations in the Night-time Care of Infants [Master of Science]. University of Otago, 2016.
27 Pease A, Ingram J, Blair PS, et al. Factors influencing maternal decision-making for the infant sleep environment in families at higher risk of SIDS: a qualitative study. BMJ Paediatr Open 2017;1:e000133.

28 Miller LH, Fraser A, Moy R. How does cot death prevention advice influence parents' behaviour? Child Care Health Dev 2008;34:613-8.

29 Ellis C. Safely Sleeping? An Exploration of Mothers' Understanding of Safe Sleep Practices and Factors that Influence Reducing Risks in their Infant's Sleep Environment [Doctoral Thesis]. University of Warwick, 2019

30 Crane D, Ball HL. A qualitative study in parental perceptions and understanding of SIDS-reduction guidance in a UK bi-cultural urban community. BMC Pediatr 2016;16:23.

31 Moon RY, Hauck FR, Colson ER. Safe infant sleep interventions: what is the evidence for successful behavior change? Curr Pediatr Rev 2016;12:67-75.

32 Shipstone RA, Young J, Kearney L, et al. Applying a social exclusion framework to explore the relationship between sudden unexpected deaths in infancy (SUDI) and social vulnerability. Front Public Health 2020;8:563573.

33 Cowan S. Creating change: how knowledge translates into action for protecting babies from sudden infant death? Current Pediatric Reviews 2010;6:86-94. 